\title{
Two Species of Pyralinae (Lepidoptera, Pyraloidea, Pyralidae) New to China
}

\author{
Mu-jie Qi, Hui-lin Han ${ }^{1}$, Xuanvi Le and Yang-Seop Bae* \\ Division of Life Sciences, Incheon National University, Incheon, 406-772, Korea \\ ${ }^{1}$ School of Forestry, Northeast Forestry University, Harbin, 150040, China
}

\section{중국 동북지역 명나방가의 미기록 2종에 관한 보교}

치무지에 · 한휘림 ${ }^{1}$ · 레수안비 · 배양섭*

인천대학교 생명과학부, ${ }^{1}$ 중국 하얼빈 동북임업대학교 임업대학

\begin{abstract}
Two species of Pyralinae, Hypsopygia iwamotoi Kirpichnikova \& Yamanaka, 1995, and Synaphe amuralis (Hampson, 1900), are reported for the first time from China. The adults and genitalia of the species are redescribed and illustrated.
\end{abstract}

Key words: Pyralidae, Pyralinae, Hypsopygia, Synaphe, New record, Northeast China

초 록: 명나방과의 2종, Hypsopygia iwamotoi Kirpichnikova \& Yamanaka, 1995와 Synaphe amuralis (Hampson, 1900)이 중국에서는 처음 으로 보고된다. 본 연구에서는 이들 2종에 대하여 재기재하고 성충 및 생식기의 도해도를 제시하였다.

검색어: 명나방과, 명나방아과, Hypsopygia, Synaphe, 미기록종, 중국 동북지역

\section{Introduction}

The subfamily Pyralinae comprises more than 900 species in the world and is mainly distributed in tropical regions and Indo-Australian. The larvae of Pyralinae have been known as notorious pests, feeding on stored products, plants, and even dead vegetation (Munroe and Solis, 1999).

The subfamily Pyralinae can be identified by the following characteristics: head rounded, ocelli absent or present; chaetosema present; proboscis developed, labial palpus porrect or ascending, maxillary palpus usually small; forewing usually colorful, with $\mathrm{R}_{5}$ stalked with $\mathrm{R}_{4}$ and $\mathrm{R}_{3}$, hindwing $\mathrm{Sc}+\mathrm{R}_{1}$ approximate with Rs; male genitalia with uncus wide and strong; gnathos well developed, usually slim, sharped or hooked at tip, valva simple,

*Comesponding author: baeys@incheon.ac.kr

Received March 15 2013; Revised April 302013 Accepted May 102013 hairy, tegumen sclerotized, vinculum well-developed, aedeagus cylindrical, cornuti present or absent, female genitalia with slim apophyses anteriores and apophyses posteriores, corpus bursae oval, signa present or absent.

In China, about 32 genera and 150 species have been reported to date (Li et al., 2009). For the genus Synaphe, which is mainly distributed in Europe, 21 species have been reported from Europe (Leraut, 2005; Slamka, 2006, 2010) and in immediate neighboring areas of China, 5 species are reported from Russian Far East (Martin, 1986; Kirpichnikova, 1999, 2009), but only 2 species of the genus Synaphe have been reported from the rest of China, for the genus Hypsopygia, 28 species have been reported from China, 5 from Russian Far East, 13 from Japan, and 8 from South Korea (Wang, 1980; Inoue, 1982; Xu, 1997; Hua, 2005; Bae et al., 2008; Li et al., 2009; Kirpichnikova, 2009).

In the present study, two species of Pyralinae, Hypsopygia iwamotoi Kirpichnikova \& Yamanaka, 1995, and Synaphe amuralis (Hampson, 1900), are recorded from China for the first 
time. The morphology of adults and genitalia are redescribed and illustrated, the specimens examined are deposited in Northeast Forestry University (NEFU), Harbin, Heilongiiang, China.

Abbreviations used in this study are as follows: TS- type species, TL- type locality.

\section{Taxonomic accounts}

\section{Genus Hypsopygia Hübner, 1825}

Hypsopygia Hübner, 1825: 348. TS: Phalaena costalis Fabricius, 1775.

Herculia Walker, 1859, 17: 546. TS: Herculia bractealis Walker, 1859.

Cisse Walker, 1863, 27: 125. TS: Cisse nigrivitta Walker, 1863. Buzala Walker, 1863, 27: 129. TS: Buzala fuscicosta Walker, 1863.

Bejuda Walker, 1865, 34: 1273. TS: Bejuda costigeralis Walker, 1866.

Ocrasa Walker, 1866, 34: 1212. TS: Ocrasa albidalis Walker, 1866.

Pseudasopia Grote, 1873, 1: 172. TS: Pseudasopia squamealis Grote, 1873.

Bleone Ragonot, 1890, 10: 93. TS: Asopia fulvocilialis Duponchel, 1832.

Parasopia Möschler, 1890, 16: 275. TS: Parasopia dissimilalis Möschler, 1890.

Dolichomia Ragonot, 1891, 60: 32. TS: Asopia binodulalis Zeller, 1872.

Orhopygia Ragonot, 1891, 60: 29. TS: Phalaena glaucinalis Linnaeus, 1758.

Diagnosis. Small to medium sized moth. Frons rounded, without ocelli; labial palpus upturned, over vertex. Forewing $\mathrm{R}_{4}$ stalked with $\mathrm{R}_{5}$, and then anastomosed with $\mathrm{R}_{3}$. Hindwing $\mathrm{Rs}$ anastomosed with $\mathrm{M}_{1}$ near discal cell. Male genitalia with uncus various in shape; gnathos slim; valve short or slender; saccus developed, usually long or rounded or sharp in the tip; aedeagus cylindrical, long or slim, sometimes stout, with thorn-shaped cornutus, sometimes cornutus absent. Female genitalia with triangular or oval anal papilla, both of apophyses anteriores and apophyses posteriores slim and long; ductus bursae usually short or slim; corpus bursae oval or irregular pyriform, signum present or absent.

\section{Hypsopygia iwamotoi Kirpichnikova \& Yamanaka, 1995 (Figs. 1, 3-6)}

Hypsopygia iwamotoi Kirpichnikova \& Yamanaka, 1995, 14(3): 200-203, fig. 1, 2, 4; Kirpichnikova, 1999: 434; Leraut, 2006: 16; Lee \& Bae, 2007: 51. TL: Russia, Primorye Territory, Barabash-Levada.

Hypsopygia aurotaenialis Christoph, 1881: Kirpichnikova, 2009: 84

Adult (Fig. 1). Wingspan 11-18mm. Frons yellowish brown, vertex with rough and pale brown hair; labial palpus reddish brown at base, $2^{\text {nd }}$ and $3^{\text {rd }}$ segments fuscous outside, yellow brown inside, top of labial palpus with yellowish scales; maxillary palpus rather small, yellowish brown; proboscis with yellow scales at base; antenna fuscous; patagia reddish purple; tegulae dark re ddish purple at base, pale at top; abdomen fuscous dorsally, yellow ventrally. Ground color of forewing purplish red, mixed with fuscous scales irregularly, both antemedial and postmedial lines distinct and yellow, costa with several yellow spots between antemedial and postmedial line, antemedial line slightly oblique inwardly from costa to dorsum, postmedial line sinuate slightly, forming a triangle yellow spot at costa, cilia light yellow; hindwing with ground color same as forewing, antemedial line and postmedial line yellow, and convex outwardly, between the two lines, with yellow suffusion, forming a yellow band from costa to $\mathrm{CuP}$; cilia light yellow as forewing.

Male genitalia (Figs. 3-5). Uncus short, thumb-shaped, rounded slightly on the top, with short hairs dorsally; gnathos long, slim, broad at base, and gradually narrowed to the tip, hooked slightly at apex; valve hairy, long and slim, with rounded and narrowed top; saccus rather slim and long, with slightly shape tip; juxta rounded and sclerotized slightly. Aedeagus evenly cylindrical, slim and long, with a thorn-shaped cornutus.

Female genitalia (Fig. 6). Both apophyses posteriores and apophysis anteriores slender and long, the former one about 1.6 times as long as the latter. Ductus bursae about 0.9 times as long as corpus bursae, with a sclerotized ring, ductus seminalis from 
top of ductus bursae. Corpus bursae oval or pyriform, signum T-shaped, the vertically directed thorn strong and largest.

Material examined. $10^{7}, 1$ o , China: Prov. Liaoning, Jianchang, Mt. Bailangshan, 12. VII. 2011 (Qi M. J.); $2 \sigma^{\top} \sigma^{\star}, 1$ 우, Prov. Jilin, Mt. Changbai, 31. VII. 2000 (K. T. Park \& J. S. Lee), Slide No. UIK-2682, UIK-2683, UIK-2684; 1 \& , Prov. Liaoning, Mt. Qianshan, 9. VII. 2011 (Qi M. J.); 2 우 우, Prov. Heilongjiang, Dailing, Liangshui, 28. VII. 2011 (Qi M. J. \& Jin X. X).

Distribution. China (Liaoning, Jilin, Heilongjiang); Far East of Russia (Primorye Territory); Korea; Japan.

Remarks. This species is similar to the species H. regina, but it can be distinguished from the latter by the following characteristics: the color of hindwing same as the forewing; hindwing with a distinct yellow band; the uncus thumb-shaped and stumpy, much wider than that of $H$. regina (Fig. 7); in the female genitalia, the ductus bursae shorter than that of H. regina.

\section{Genus Synaphe Hübner, 1825}

Synaphe Hübner, 1825: 347. TS: Pyralis angustalis [Denis \& Schiffermüller], 1775.

Cledeobia Stephens, 1829: 159. TS: Pyralis angustalis [Denis \& Schiffermüller], 1775.

Mitopoda Mann, 1854: 573. TS: Phalaena punctalis Fabricius, 1775.

Diagnosis. Frons oval, antenna bipectinate. Labial palpus protended flatly, scaled at the second segments, pointed at the end, drooping slightly; maxillary palpus with brush-shaped tip. Forewing with $\mathrm{R}_{3}, \mathrm{R}_{4}$ fused, and then stalked with $\mathrm{R}_{5} . \mathrm{R}_{3+4}$ and $\mathrm{R}_{5}$ slightly fused with $\mathrm{M}_{1}$ at the upper corner of cell; $\mathrm{M}_{2}, \mathrm{M}_{3}$ approaching at base. Hindwing Rs stalked with $M_{1} ; M_{2}, M_{3}$ stalked with each other.

Until now only two species have been reported from China: Synaphe bombycalis Denis \& Schiffermüller, 1775, distributed in Qinghai Province, and Synaphe graeseri (Sauber, 1899), which is reported from Shanxi Province.

Synaphe amuralis (Hampson, 1900) (Figs. 2, 8-10)

Cledeobia amuralis Hampson, 1900: 384, Pl. 3, fig. 32. TL: Upper Amur, Russia.
Synaphe amuralis (Hampson, 1900): Kirpichnikova, 1999: 437; Leraut, 2005: 42, fig. 75; Kirpichnikova, 2009: 96, Pl. 5, fig. 6.

Adult (Fig. 2). Wingspan $21 \mathrm{~mm}$. Frons dark brown. Vertex with yellowish brown scales. Proboscis yellowish brown, with scales at base, maxillary palpus small and brown. Labial palpus strong, brown, and protended flatly, 3 times as long as maxillary palpus, antennae brown, bipectinate, about $2 / 3$ length of forewing, patagium yellowish brown, tegula yellowish brown mixed with black scales, dorsal thorax black. Legs with black and brown mixed in femur, the other segments yellowish brown, hindleg with tarsus yellow. Forewing reddish brown, postmedial line white, inwardly oblique from costa, and outwardly oblique to dorsum between $\mathrm{CuA}_{2}$ and $1 \mathrm{~A}$, antemedial line white, all the basal area reddish brown, upper of medial area reddish brown, lower area with reddish scales between $\mathrm{CuA}_{2}$ and $1 \mathrm{~A}$, outside of postmedial line all reddish brown. Cilia grey. Hindwing dark brown to black, postmedial line white, from costa to dorsum, at $2 / 3$ of the line with a distinct outward sharp angle, the margin of postmedial line with few yellowish brown scales, inside area of postmedial line with reddish and black scales mixed. Cilia yellowish brown.

Male genitalia (Figs. 8-10). Uncus basal broad, form a sharp-shaped near tip, the end of uncus linguiform, both sides of uncus with hairs, gnathos hook-shaped, slightly longer than uncus, valva basal broad, costa straight, dorsum rounded, saccus small, rounded, aedeagus cylindrical, with one pin-shaped, sclerotized cornutus, about $1 / 3$ length of aedeagus.

Female genitalia. Unknown.

Material examined. $10^{x}$, China: Province Liaoning, Jianchang county, Bailangshan Mt., 19-23. V. 2009 (Qi M. J. and Hu Y. Q.), Slide No. NEFU-010.

Distribution. China (Liaoning Province); Russia (Amur); Europe.

Remarks. This species was first described by Hampson (1900) as Cledeobia amuralis from the upper Amur, which belongs to Far East of Russia. It never has been collected from China, and this is the first time reporting this species from China. It is similar to $S$. bombycalis, but it can be distinguished by the following characters: the antemedial line of forewing without sharp convexed outwardly, and hindwing dark brown, only postmedial line white; in $S$. bombycalis the antemedial line 


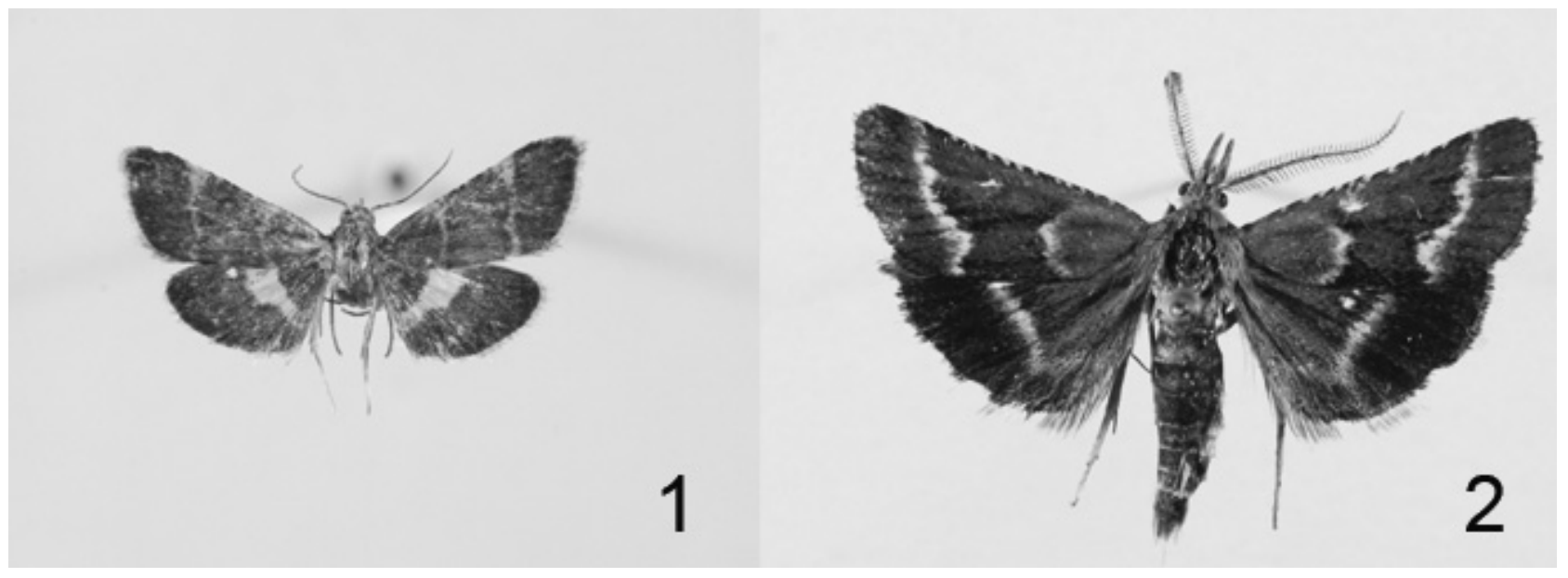

Figs. 1-2. Adult. 1. Hypsopygia iwamotoi Kirpichnikova \& Yamanaka, 1995; 2. Synaphe amuralis (Hampson, 1900).

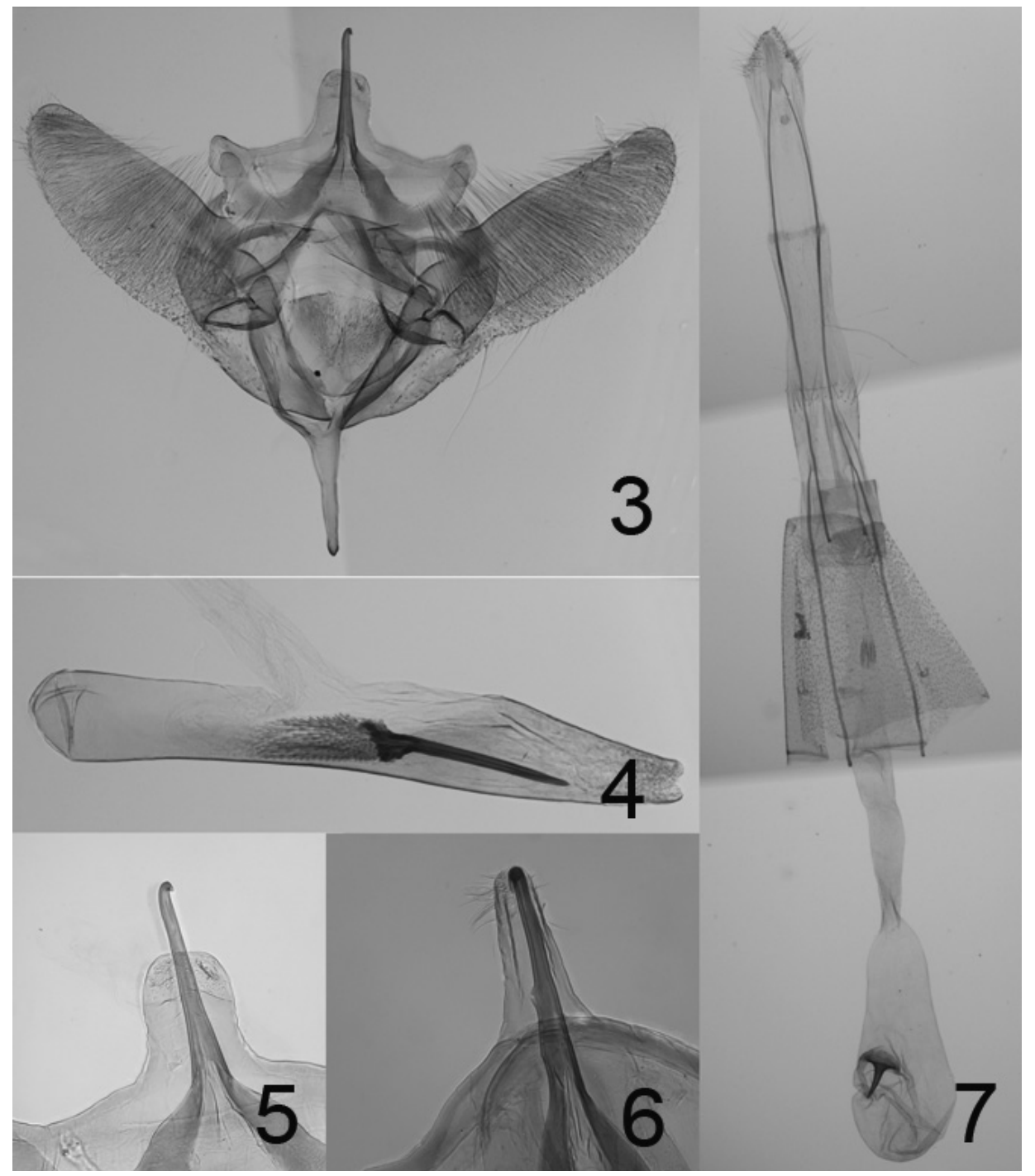

Figs. 3-7. Genitilia. 3. Male genitalia of $H$. iwamotoi; 4. Aedeagus of $H$. iwamotoi; 5. Uncus of $H$. iwamotoi; 6. Uncus of $H$. regina; 7. Female genitalia of $H$. iwamotoi. 


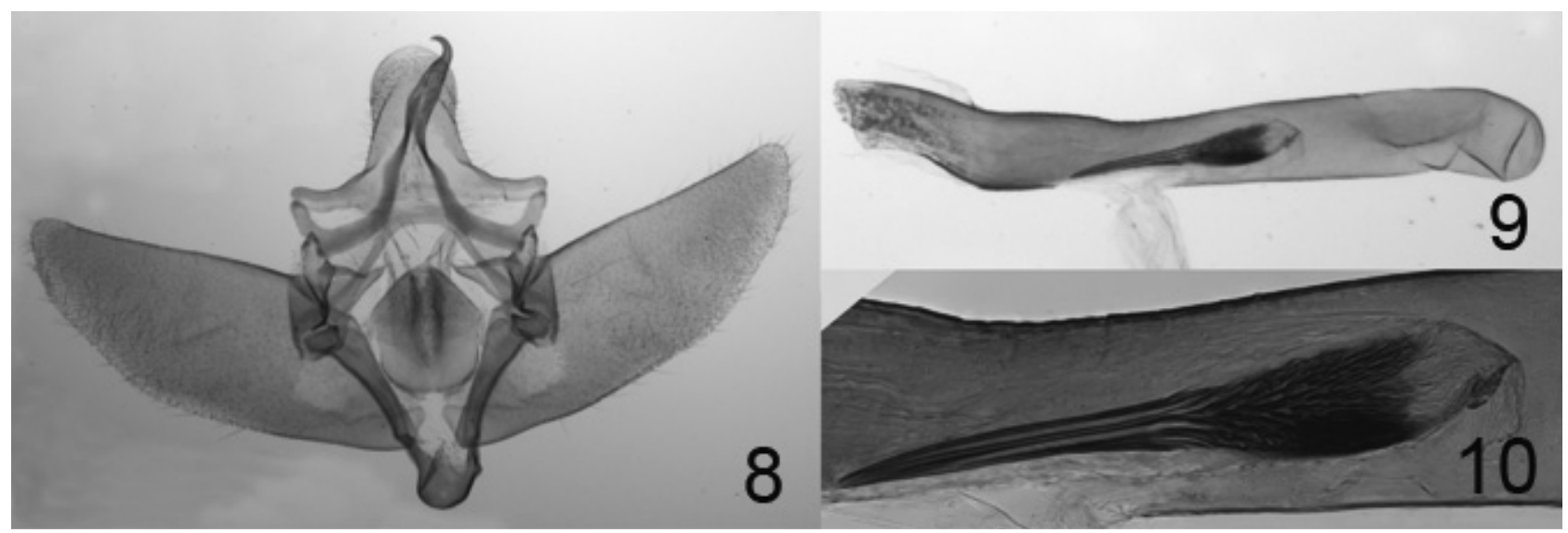

Figs. 8-10. Genitalia; 8. Male genitalia of Synaphe amuralis, 9. Aedeagus of S. amuralis, 10. Cornutus enlarged of S. amuralis.

formed sharply convex under the discoidal cell, and the distal discoidal stigma concave inwardly, and with white spots on both sides, and hindwing yellow inside the postmedial line.

\section{Acknowledgments}

We express our sincere thanks to Mr. Patrice Leraut, National Museum of Natural History, Paris, France, for his helpful opinions and for providing some important references. We are also grateful to Dr. Valentina Kirpichnikova, Mountain-Taiga Station, Far Eastern Branch of Russian Academy of Sciences, for her important advice and references. Moreover, we also express our thanks to Dr. John B. Heppner, Florida Museum of Natural History, University of Florida, Gainesville, for his help in the present study. This study was supported in part by the research grant of the Korea National Arboretum.

\section{Literature Cited}

Bae, Y.S., Byun, B.K., Paek, M.K., 2008. Pyralid Moths of Korea (Lepidoptera, Pyraloidea), Korea National Arboretum, Seoul.

Grote, A.R., 1873. Description of the genera Argyrophyes and Condylolomia and of a species of Deuterollyta. Bulletin of the Buffalo Society of Natural Science. 1, 175-177.

Hampson, G., 1900. New Palaearctic Pyralidae. Trans. Ent. Soc. Lond. 2, 369-401.

Hua, L.Z., 2005. List of Chinese Insects (III), Sun Yat-sen University Press, Guangzhou.

Hübner, J., 1816-1826. Verzeichniß bekannter Schmettlinge, bey dem Verfasser zu finden, Augsburg.
Inoue, H., 1982. Pyralidae, in: Inoue, H. et al. (Eds.), Moths of Japan. Kodansha, Tokyo, pp. 1: 307-404, 2: 223-254.

Kirpichnikova, V.A., 1999. Order Pyralidae, in: Kononenko, V.S. (Eds.), Key to the insects of Russian Far East Volume 5, part 2. Dalnauka, Vladivostok, pp. 437-438.

Kirpichnikova, V.A., 2009. Pyralids (Lepidoptera, Pyralidae, Crambidae) of the Fauna of Russian Far East, Dalnauka, Vladivostok.

Kirpichnikova, V.A., Yamanaka, H., 1995. New and unrecorded species of the genus Hypsopygia Hübner Lepidoptera, Pyralidae, Pyralinae from the Primorye Territory, Russia. Tinea. 14(3), 200-203.

Lee, B.W., Bae, Y.S., 2007. A review of the tribe Pyralini Latreille (Lepidoptera, Pyralidae, Pyralinae) from Korea. Trans. Lepid. Soc. Japan. 58(1), 47-68.

Leraut, P., 2005. Étude de quelques genres et espèces de Pyrales (Lepidoptera, Pyraloidea). Revue française d'Entomologie (N.S.). 27(1), 21-44.

Leraut, P., 2006. Contribution à l'étude du genre Hypsopygia Hübner (Lepidoptera, Pyralidae). Revue française d'Entomologie (N.S.). 28(1), 5-30

Li, H.H., Ren, Y.D., 2009. Insect Fauna of Henan (Lepidoptera: Pyraloidea), Science Press, Beijing, China.

Li, H.H., Wang, S.X., 2009. The Fauna of Heibei, China (Microlepidoptera), China Agricultural Science and Technology Press, Beijing.

Mann J., 1854. Aufzählung der Schmetterlinge, gesammelt auf einer Reise nach Oberkrain und dem Küstenlande in den monaten Mai und Juni. Verhandlungen des zoologisch-botanischen Vereins in Wien. 4, 545-596

Martin, M.O., 1986. Family Pyralidae, in: Mdevedev, G.S. (Eds.), Keys to the insects of the European part of the USSR. Opredeliteli, Faune SSSR, pp. 236-237.

Möschler, H.B., 1890. Die Lepidopteren-Fauna der Insel Portorico. 
Abhandlungen herausgegeben von der Senckenbergischen Naturforschenden Gesellschaft, Frankfurt a. M. 16, 69-360.

Munroe, E., Solis, M.A., 1999. The Pyraloidea, in: Fischer, M.

(Eds.), Handbook of Zoology. IV, Arthropoda: Insecta, Lepidoptera, Moths and Butterflies. Berlin, New York, Walter de Gruyter, pp. 233-256.

Ragonot, E.L., 1890. Diagnoses de quelques espèces nouvelles de Phycites recoltées par. M. le Dr Staudinger en Algerie. Bulletin des séances de la Société entomologique de France. 10, 109-111.

Ragonot, E.L., 1891. Essai sur la classification des Pyralites. Annales de la Société Entomologique de France. 60, 15-114.

Slamka, F., 2006. Pyraloidea (Lepidoptera) of Europe, Volume 1, Bratislava.

Slamka, F., 2010. Pyraloidea (Lepidoptera) of Central Europe, Bratislava

Stephens, J.F., 1829. The nomenclature of British insects, being a list of such species as are contained in the systematic catalogue of British insects, and forming a guide to their identification, London.

Walker, F., 1859. Pyralides. List of the Specimens of Lepidopterous Insects in the Collection of the British Museum. Edward Newman, London. 18, 509-798.

Walker, F., 1863. Crambites \& Tortricites. List of the Specimens of Lepidopterous Insects in the Collection of the British Museum. Edward Newman, London. 27, 1-286.

Walker, F., 1866. Supplement 4. List of the Specimens of Lepidopterous Insects in the Collection of the British Museum.

Edward Newman, London. 34, 1121-1533.

Wang, P.Y., 1980. Economic Insect Fauna of China (Lepidoptera: Pyralidae), Science Press, Beijing.

Xu, Z.G., 1997. Iconographia of Microlepidoptera in Qinghai Province of China, Agric. Sci. \& Tech. Press, Beijing. 